\title{
KONSEP NILAI KENYAMANAN RUANG PUBLIK DARI SUDUT PANDANG ANAK-ANAK DI KECAMATAN KOTABUMI
}

\author{
Nisfi Eka Sulistiorini ${ }^{1}$, Lutfi Setianingrum ${ }^{1}$ \\ ${ }^{1}$ Institut Teknologi Sumatera, Jl. Terusan Ryachudu, Way Huwi, Jati Agung, Lampung Selatan \\ ${ }^{1}$ Email : nisfisulis@gmail.com \\ DOI: 10.35472/jppk.v1i1.439
}

\begin{abstract}
Comfort assurance is frequently regarded as a problem for users of public open spaces, particularly children. Having a sense of comfort public open space attachment is essential for children's mental and physical well-being. This research aimed to find of the concept of the value of space comfort from the perspective of the children in Kotabumi District. The methodology in this study uses qualitative analysis with a naturalistic inductive-qualitative research approach. According to the analysis, the value of public space comfort formed from the perspective of children is formed by: 1) the values instilled by parents; 2) activities carried out by children; and 3) children's social interactions. The concept of value for space comfort creates criteria for a child-friendly environment. These criteria include: 1) a room close to the child's residence; 2) spaces with plenty of space and cool temperatures so that children can freely engage in activities such as playing and studying; 3) Adequate space for each age group of children; 4) Space that children can enjoy for free; and 5) a room with various types of games based on the child's age group.
\end{abstract}

Keywords: Space Comfort Value, Comfort Space Criteria, Children, Public Open Space in Kotabumi District.

\section{A. PENDAHULUAN}

Salah satu elemen perkotaan yang memiliki peranan penting adalah ruang publik, ruang publik memiliki peranan sebagai pusat interaksi dan komunikasi bagi masyarakat baik formal maupun informal, individu maupun kelompok. Menurut (Pratomo et al., 2019). Ruang menjadi wadah yang dapat menampung seluruh aktivitas masyarakat dan menambah citra sebuah kawasan (Banapon, 2017). Aktivitas pada ruang dapat menjadi indikator kualitas ruang publik perkotaan (Gehl, 2006). Keberadaan ruang publik tidak dapat berdiri sendiri. Hal tersebut menjelaskan bahwa keberadaan ruang publik harus dirancang sebagaimana mestinya sehingga memberi manfaat bagi anak-anak yang menggunakannya. Hal ini dikarenakan ruang publik termasuk kedalam bagian konteks perancangan kota (Shirvani, 1985).

Ditengah keterbatasan lahan perkotaan serta kurangnya perhatian terhadap fasilitas penunjang ruang terbuka publik, secara tidak langsung membuat pemerintah harus lebih memperhatikan penyediaan ruang terbuka publik yang nyaman serta memiliki nilai keberlanjutan dalam aspek lingkungan. Kenyamanan berkaitan dengan kualitas hidup 
masyarakat sehingga kenyamanan menjadi salah satu indikator tingkat kelayakhunian sebuah ruang publik. Seiring berkembangnya kota, nilai kenyamanan merupakan hal yang disinyalir menunjukkan karakter kota. Karakter kota tersebut merupakan penilaian dari apa yang dirasakan oleh anak-anak yang melakukan aktivitas dalam ruang dengan adanya kenyamanan yang dibentuk dalam ruang tersebut.

Untuk membentuk karakter kota yang baik, Kabupaten Lampung Utara membangun sebuah ruang publik dan diperuntukkan untuk anak-anak. Hal ini tertuang dalam Dokumen Masterplan Ruang Terbuka Hijau Kabupaten Lampung Utara. Ruang publik ini dibangun di wilayah perkotaan Kabupaten Lampung Utara, tepatnya di Kecamatan Kotabumi. Ruang publik ini digunakaan oleh masyarakat Kabupaten Lampung Utara sebagai tempat untuk berekreasi. Namun, adanya ruang publik yang diperuntukkan untuk anak-anak menimbulkan beberapa permasalahan, diantaranya kondisi ruang publik yang sepi dari kunjungan anak-anak serta banyaknya pedagang kaki lima yang memenuhi sekitar ruang publik tersebut. Kondisi tersebut menimbulkan berbagai pertanyaan, apakah ruang publik tersebut tidak dapat memberikan kenyamanan kepada anak dalam beraktivitas sehingga anak-anak enggan untuk menggunakan ruang publik tersebut sebagai ruang untuk anak-anak berkegiatan.

Untuk itu diperlukan kajian secara mendalam mengenai konsep nilai kenyamanan ruang dari sudut pandang anak-anak yang berada di Kecamatan Kotabumi. Kajian tersebut dilakukan untuk mengetahui konsep nilai kenyamanan ruang publik dari sudut pandang anak-anak sebagai salah satu indikator perancangan ruang publik untuk anak khususnya untuk wilayah Kabupaten Lampung Utara, tepatnya di Kecamatan Kotabumi.

\section{B. METODE PENELITIAN}

\section{Lokasi dan Waktu Penelitian}

Penelitian ini dilakukan di Kecamatan Kotabumi, Kabupaten Lampung Utara. Kecamatan Kotabumi merupakan ibu kota Kabupaten Lampung Utara. Kecamatan Kotabumi memiliki luas wilayah sebesar $59,11 \mathrm{Km} 2$ merupakan $2.17 \%$ dari wilayah total Kabupaten Lampung Utara. Secara administratif, wilayah Kecamatan Kotabumi di sebelah Utara berbatasan dengan Kecamatan Sungkai Jaya, di sebelah Selatan berbatasan dengan Kecamatan Kotabumi Selatan, di sebelah Barat berbatasan dengan Kecamatan Abung Barat dan Kecamatan Abung Kunang, serta di sebelah Timur berbatasan dengan Kecamatan Kotabumi Utara. Penelitian ini dilaksanakan pada bulan November 2019 Juni 2020. Berikut merupakan peta konsentrasi wilayah penelitian di Kecamatan Kotabumi 


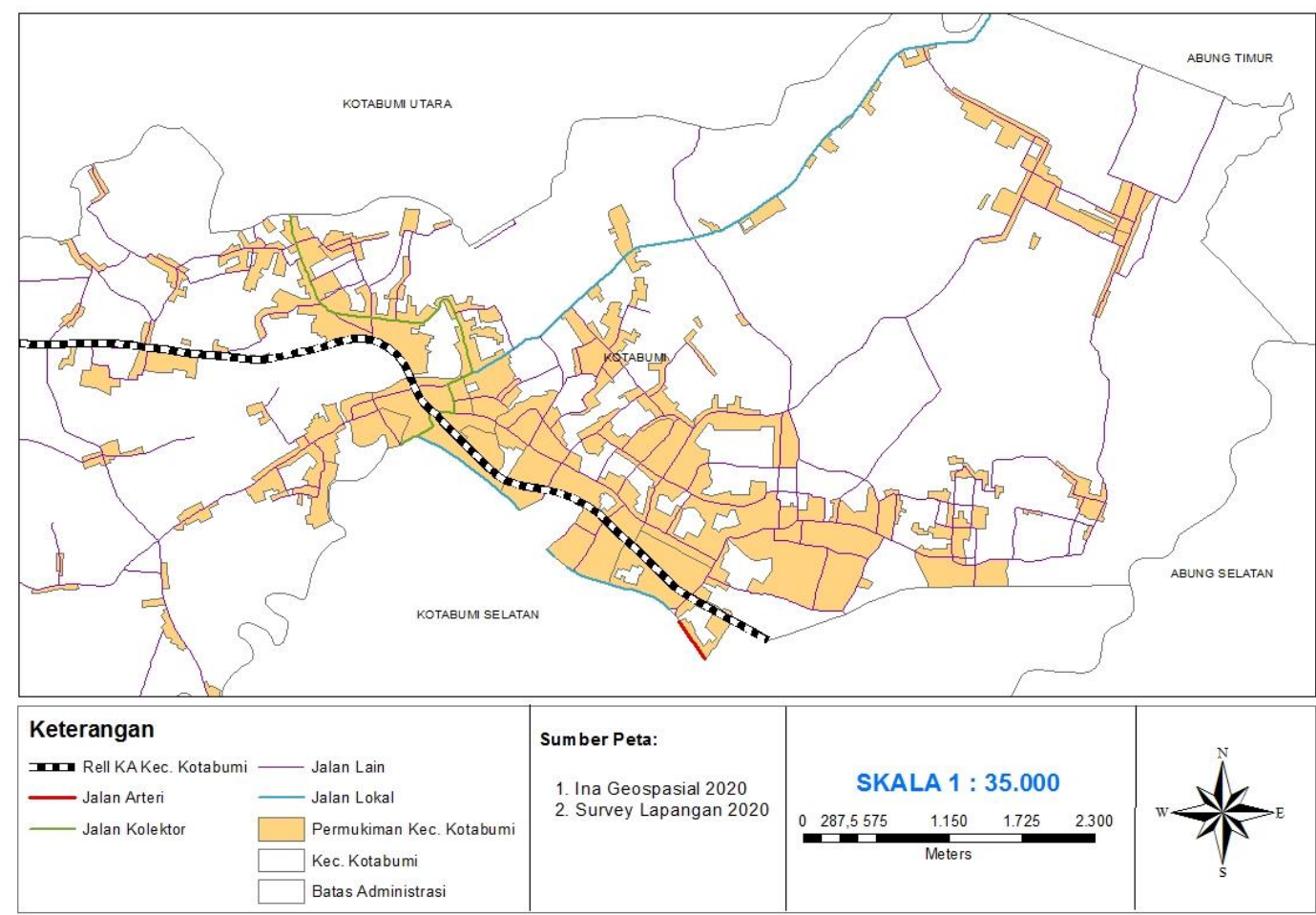

Sumber : gambar hasil ArcGIS, 2020

Gambar 1. Peta Konsentrasi Wilayah Pengambilan Sampel di Kecamatan Kotabumi

Berdasarkan data Kecamatan Kotabumi dalam angka 2018, jumlah penduduk Kecamatan Kotabumi tahun 2017 sebanyak 52.548 jiwa yang terdiri atas 26.508 jiwa penduduk laki-laki dan 26.040 jiwa penduduk perempuan. Sementara itu besarnya angka rasio jenis kelamin tahun 2017 penduduk laki-laki terhadap penduduk perempuan sebesar 101,9 (BPS Lampung Utara, 2018).

Berdasarkan kelompok umur, jumlah penduduk Kabupaten Lampung Utara pada tahun 2017 didominasi oleh penduduk dengan umur 0-9 tahun. Dimana kelompok umur 0-4 tahun berjumlah 60.220 jiwa dengan komposisi perempuan sebanyak 29.356 jiwa dan laki-laki sebanyak 30.864 jiwa. Sedangkan penduduk dengan kelompok umur 5-9 tahun berjumlah 60.078 jiwa dengan komposisi perempuan sebanyak 29.279 jiwa laki-laki sebanyak 30.799 jiwa. Berikut merupakan tabel jumlah penduduk berdasarkan kelompok umur:

Tabel 1. Jumlah Penduduk Kabupaten Lampung Utara berdasarkan Kelompok Umur

\begin{tabular}{ccccc}
\hline $\begin{array}{c}\text { Kelompok Umur } \\
\text { (Tahun) }\end{array}$ & $\begin{array}{c}\text { Laki-Laki } \\
\text { (Jiwa) }\end{array}$ & $\begin{array}{c}\text { Perempuan } \\
\text { (Jiwa) }\end{array}$ & $\begin{array}{c}\text { Jumlah } \\
\text { (Jiwa) }\end{array}$ & $\begin{array}{c}\text { Persentase } \\
(\boldsymbol{\%})\end{array}$ \\
\hline $\mathbf{0 - 4}$ & 30.864 & 29.356 & 60.220 & 10,13 \\
$\mathbf{5 - 9}$ & 30.799 & 29.279 & 60.078 & 10,10 \\
$\mathbf{1 0 - 1 4}$ & 29.486 & 27.880 & 57.366 & 9,65 \\
$\mathbf{1 5 - 1 9}$ & 27.594 & 26.183 & 53.777 & 9,04 \\
$\mathbf{2 0 - 2 4}$ & 26.445 & 24.326 & 50.771 & 8,54 \\
$\mathbf{2 5 - 2 9}$ & 23.994 & 22.500 & 46.494 & 7,82 \\
\hline
\end{tabular}




\begin{tabular}{ccccc}
\hline $\begin{array}{c}\text { Kelompok Umur } \\
\text { (Tahun) }\end{array}$ & $\begin{array}{c}\text { Laki-Laki } \\
\text { (Jiwa) }\end{array}$ & $\begin{array}{c}\text { Perempuan } \\
\text { (Jiwa) }\end{array}$ & $\begin{array}{c}\text { Jumlah } \\
\text { (Jiwa) }\end{array}$ & $\begin{array}{c}\text { Persentase } \\
(\%)\end{array}$ \\
\hline $\mathbf{3 0 - 3 4}$ & 22.823 & 22.046 & 44.869 & 7,55 \\
$\mathbf{3 5 - 3 9}$ & 22.135 & 22.548 & 44.683 & 7,51 \\
$\mathbf{4 0 - 4 4}$ & 21.571 & 21.991 & 43.562 & 7,33 \\
$\mathbf{4 5 - 4 9}$ & 19.895 & 19.939 & 39.834 & 6,70 \\
$\mathbf{5 0 - 5 4}$ & 17.197 & 16.881 & 34.078 & 5,73 \\
$\mathbf{5 5 - 5 9}$ & 13.412 & 13.353 & 26.765 & 4,50 \\
$\mathbf{6 0 - 6 4}$ & 10.097 & 9.421 & 19.518 & 3,28 \\
$\mathbf{6 5 +}$ & 6.415 & 6.162 & 12.577 & 2,12 \\
\hline Jumlah & $\mathbf{3 0 2 . 7 2 7}$ & $\mathbf{2 9 1 . 8 6 5}$ & $\mathbf{5 9 4 . 5 9 2}$ & $\mathbf{1 0 0}$ \\
\hline
\end{tabular}

Sumber : BPS Kabupaten Lampung Utara, 2018

Kabupaten Lampung Utara memiliki beberapa ruang terbuka publik diantaranya Taman Sahabat, Ruang Publik Payan Mas, dan Islamic Center. Taman Sahabat merupakan ruang terbuka yang diperuntukkan untuk anak-anak. Taman Sahabat berada ditengah-tengah Perkotaan Wilayah Kabupaten Lampung Utara, tepatnya berada di Jl. Jenderal Sudirman, Cempedak, Kotabumi, Kabupaten Lampung Utara, Lampung 34516. Kondisi Taman Sahabat sudah cukup baik dikerenakan telah tersedianya permainan untuk anak-anak dan berbagai macam makan-makanan. Selain itu, suasana Taman Sahabat yang sangat sejuk karena terdapat pohon besar yang rindang.

Sebagai bentuk dari ruang terbuka publik, Taman Sahabat terdiri dari beberapa komponen ruang yang setiap komponen ruang tersebut memiliki fungsi yang berbeda. Secara eksisting, Taman Sahabat terdiri dari berbagai fasilitas-fasilitas pendukung. Berikut merupakan fasilitas ruang Taman Sahabat:

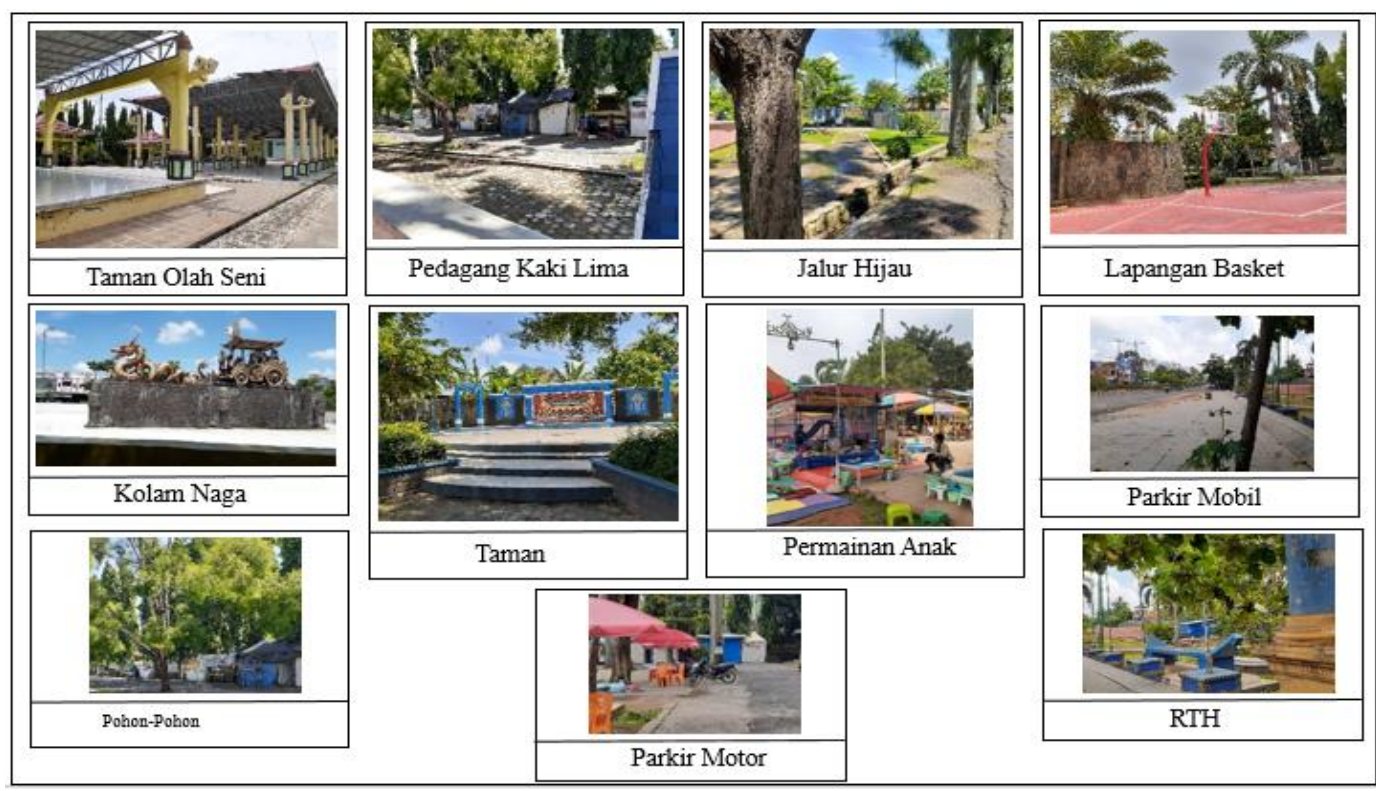

Sumber : hasil analisis, 2020

Gambar 2. Ketersediaan Fasilitas Pendukung Taman Sahabat 


\section{Pendekatan dan Metode Penelitian}

Penelitian ini menggunakan metode penelitian kualitatif dengan pendekatan penelitian induktif-kualitatif naturalistik (Loncoln S., 1984). Penelitian induktif merupakan penelitian yang berangkat dari peristiwa di lapangan yang kemudian dianalisis menjadi suatu konsep hingga teori baru. Penelitian induktif bersifat kualitatif, dimana penelitian ini bertujuan untuk menemukan nilai kenyamanan ruang dari sudut pandang anak-anak.

Penelitian ini dilakukan dengan mengamati pola tingkah laku anak-anak secara natural, yang bertujuan untuk memahami tafsiran dan bahasa anak-anak tentang lingkungan sekitarnya, berinteraksi dengan anak-anak yang berhbungan dengan fokus penelitian yang bertujuan untuk mencoba memahami, menggali pengalaman dan pandangan anak-anak, serta melakukan kajian terhadap perilaku anak-anak di dalam ruang yang bertujuan untuk mendapat informasi atau data mengenai nilai kenyamanan ruang dari sudut pandang anak-anak.

\section{Metode Koleksi Data}

Metode koleksi data merupakan metode yang digunakan untuk mengumpulkan datadata dan informasi yang dibutuhkan. Penelitian ini menggunakan metode pengumpulan data tiga tahap yaitu grand tour, debriefing, dan mini tour.

Tahap grand tour adalah tahap awal peneliti yang bertujuan untuk mengumpulkan informasi sebanyak-banyaknya dan seluas-luasnya mengenai pandangan anak-anak terhadap nilai kenyamanan ruang. Pada fase grand tour proses pengumpulan data bersifat eksploratif. Informasi yang didapatkan dilakukan dengan melakukan wawancara dan observasi. Setelah informasi yang dibutuhkan terkumpul kemudian dilakukan tahapan debrifieng. Tahap debriefing adalah tahapan koleksi data yang bertujuan untuk mengelompokkan informasi-informasi dalam tema tertentu yang selanjutnya didalami dalam tahap mini tour.

Tahap mini tour adalah tahapan akhir dalam metode koleksi data yang bertujuan untuk mendalami tema-tema yang telah dikelompokkan dalam tahapan debriefing. Proses pengumpulan data dalam tahap mini tour bersifat ekspansionis. Proses koleksi data pada penelitian ini terikat pada tiga kriteria trustworthiness. Data yang akan dikumpulkan berupa data kualitatif yang diperoleh melalui pengamatan langsung di lapangan melalui observasi, wawancara, dan dokumentasi. Pada tahap mini tour ini, peneliti harus mempertimbangkan kejenuhan data dan memahami profil narasumber. Tahap mini tour dapat dihentikan jika sudah terjadi kejenuhan data. Dalam hal ini peneliti harus melakukan klarifikasi silang untuk meyakinkan kebenaran data yang diperoleh. Klarifikasi silang ini dilakukan dengan menanyakan hal yang sama pada narasumber yang berbeda (triangulasi) atau menanyakan pertanyaan yang sama pada narasumber yang sama di waktu yang berbeda. Proses klarifikasi silang dilakukan secara berulang hingga data penelitian benar-benar jenuh. Informasi dikatakan jenuh ketika informasi yang sama didapatkan berulang kali. Jika data penelitian sudah jenuh, maka tahap mini tour telah selesai.

\section{Metode Analisis Data}

Metode analisis data yang digunakan dalam penelitian ini ada tiga tahap, yaitu: 1) Analisis Induksi yang terdiri dari induksi empirikal dan induksi intensional; 2) in-member 
check; dan 3) eksternal audit. Analisis dalam penelitian ini terikat pada kepercayaan dasar peneliti naturalistik berupa temuan dan lingkup subtansi penelitian berfokus pada yang indrawi dan penyebabnya sampai pada tujuan/makna (Loncoln S., 1984). Proses analisis data dilakukan secara terus menerus, sehingga datanya sudah jenuh.

Induksi empirikal merupakan analisis induksi yang dilakukan dengan mengelompokkan unit-unit informasi yang diperoleh dari hasil wawancara mendalam, observasi, dan catatan lapangan menjadi tema-tema empiris. Tahap ini dinamakan tahap kategorisasi. Tujuan dari analisis induksi ini adalah untuk memperoleh informasi yang jelas yang dilakukan dengan penyederhanaan serta transformasi data yang diperoleh dari observasi, wawancara mendalam, dan catatan lapangan. Proses ini dinamakan proses reduksi data. Kategorisasi adalah proses mengumpulkan kembali unit-unit informasi hasil dari mini tour untuk membentuk tema-tema (Setianingrum, 2018). Proses kategorisasi mereduksi hasil unit informasi yang sangat banyak menjadi 24 tema. Pada proses kategorisasi ini ada kemungkinan terbentuk tema baru, yang melengkapi tematema hasil debriefing. Dalam penelitian ini terbentuk beberapa tema baru yang semula berjumlah 12 tema menjadi 24 tema, serta terjadinya beberapa pengubahan beberapa penamaan tema menjadi lebih dalam. Proses penamaan tema-tema berdasarkan informasi yang terkumpul inilah disebut dengan proses abstraksi. Abstraksi dilakukan hampir bersamaan dengan proses kategorisasi. Analisis dilanjutkan pada tahan induksi intensional.

Selanjutnya adalah induksi intensional yang dilakukan dengan menggabungkan tema-tema empiris menjadi suatu sub-konsep dan penggabungan sub-sub konsep kedalam suatu konsep (Loncoln S., 1984). Penggabungan tema-tema dan sub-sub konsep tersebut didasarkan atas dasar keterhubungan unit-unit informasi yang terkandung lebih dari satu tema atau sub-konsep. Proses inilah dinamakan reduksi eidetic (reduksi berdasarkan keterhubungan). Hasil dari proses ini dituangkan kedalam bentuk bagan/diagram. Setelah semua proses tersebut selesai, maka dilakukan proses abstraksi. Hal ini bertujuan untuk memperoleh informasi yang jelas dari data yang dihasilkan, sehingga kesimpulan yang dihasilkan dapat dipertanggung jawabkan oleh peneliti.

In-member check adalah metoda analisis yang bertujuan untuk menilai apakah hasil abstraksi sudah akurat(Loncoln S., 1984; Setyaningrum, 2018). Setelah abstraksi dinyatakan akurat, tahap selanjutnya adalah penyusunan kesimpulan. Proses pengambilan kesimpulan dalam penelitian kualitatif dilakukan secara bertahap. Pertama, melakukan verifikasi data seiring bertambahnya data terhadap simpulan sementara yang telah dibuat. Kedua, menarik kesimpulan akhir setelah kegiatan pertama selesai.

Tahap selanjutnya adalah eksternal audit yang tidak hanya dilakukan di akhir penelitian, melainkan dilakukan di setiap tahap penelitian. Eksternal adit bertujuan untuk membantu peneliti menjaga supaya penelitiannya tetap memenuhi syarat penelitian naturalistik dengan memenuhi tiga kriteria trutstworthiness penelitian naturalistik (Loncoln S., 1984). Ketiga kriteria tersebut meliputi, kredibilitas, dependabilitas, dan konfirmabilitas. Kriteria kredibilitas, dependabilitas, dan konfirmabilitas dipenuhi pada saat proses koleksi data dan analisis data. Audit eksternal dilakukan oleh peneliti dan dosen pembimbing selaku audit eksternal secara bersamaan. 


\section{Instrumen Penelitian}

Instrumen dalam penelitian ini adalah human instrument(Loncoln S., 1984; Setyaningrum, 2018). Human instrument terdiri dari dua bagian yaitu narasumber dan peneliti. Narasumber berperan sebagai pemegang informasi sementara peneliti berperan sebagai penggali informasi. Sepanjang penelitian, peneliti melihat segala dari sudut pandang narasumber. Untuk dapat melakukannya, peneliti berusaha dengan benar-benar memahami narasumber memandang sesuatu dalam lingkungannya. Pemahaman ini dapat dibentuk dengan cara:

1) Keterlibatan dengan narasumber dalam kurun waktu yang panjang

2) Observasi terus menerus

3) Wawancara mendalam

Narasumber dalam penelitian ini adalah anak-anak umur 9-14 tahun yang berada di Kecamatan Kotabumi, anak-anak yang melakukan kegiatan di Taman Sahabat serta orang tua yang memiliki anak berumur 9-14 tahun di Kecamatan Kotabumi. Narasumber dalam penelitian ini berjumlah 24 anak-anak usia 9-14 tahun dan 2 orang tua yang memiliki anak umur 9-14 tahun. Narasumber dari penelitian ini dipilih berdasarkan karakteristik yang telah ditentukan. Apabila peneliti bertemu dengan anak-anak umur 9-14 tahun dan orangtua yang memiliki anak umur 9-14 tahun yang berada di Kecamatan Kotabumi, maka orang tersebut dijadikan peneliti sebagai narasumber dalam penelitian ini.

\section{HASIL DAN PEMBAHASAN}

Analisis induksi dalam penelitian ini terdiri dari dua tahap yaitu induksi empirikal dan induksi intensional (Loncoln S., 1984). Proses induksi empirikal dilakukan dengan mengelompokkan unit-unit informasi menjadi tema-tema. Proses induksi empirikal dalam penelitian ini menghasilkan 24 tema empiris. Tema-tema tersebut diantaranya, yaitu: 1) Ruang Bermain; 2) Cara Bermain; 3) Jenis Permainan Anak; 4) Alasan Anak Keluar Rumah; 5) Waktu Anak Keluar Rumah; 6) Kegiatan Anak Sehari-hari; 7) Kegiatan Anak Mingguan; 8) Kegiatan Anak Bulanan; 9) Ruang Belajar; 10) Cara Belajar; 11) Ruang Digital; 12) Sosok Orang Tidak Dikenal; 13) Ruang Sekolah; 14) Nilai Kenyamanan Ruang; 15) Komponen Ruang Taman Sahabat; 16) Tempat Pengajian Anak; 17) Pembagian ruang; 18) Fungsi Ruang; 19) Taman Sahabat dalam Sudut Pandang AnakAnak; 20) Cara Anak-Anak Memandang Taman Sahabat; 21) Anak Laki-Laki dalam Ruang; 22) Anak Perempuan dalam Ruang; 23) Ikatan Orang Tua dengan Anak; 24) Pandangan Anak Terhadap Wabah Menular. 24 tema yang dihasilkan dari tahap induksi empirikal ini merupakan hasil dari perkembangan unit-unit informasi yang didapatkan pada saat melakukan grand tour, debrifieng dan mini tour. Tema empiris ini berkembang dari tema yang semula berjumlah 12 tema yang kemudian berkembang menjadi 14 tema, selanjutnya berkembang kembali menjadi 17 tema, dan akhirnya menjadi 24 tema. Berikut merupakan bagan induksi unit-unit informasi yang mendukung tema-tema empiris. 


\begin{tabular}{|l|}
\hline UNIT INFORMASI \\
\hline 2. Kriteria Ruang \\
\hline 3. Jenis Permainan \\
\hline 4. Jenis Kelamin \\
\hline 5. Tipe Permainan \\
\hline 6. Kelompok Umur \\
\hline 7. Waktu \\
\hline 8. Tempat/Lokasi berkegiatan \\
\hline 9. Jenis Kegiatan \\
\hline 10. Orang Tua \\
\hline 11. Pengaruh Teman \\
\hline 12. Jenis Liburan \\
\hline 13. Jarak \\
\hline 14. Fasilitas \\
\hline 15. Sistem Belajar \\
\hline 16. Keterbatasan Ruang \\
\hline 17. Fungsi Ruang \\
\hline 18. Interaksi \\
\hline 19. Komponen Ruang \\
\hline 20. Batasan Ruang \\
\hline 21. Jenis Ruang \\
\hline 22. Bentuk Ruang \\
\hline 23. Pembagian Ruang \\
\hline 24. Jangkauan Kegiatan \\
\hline
\end{tabular}

Sumber : hasil analisis, 2020

Gambar 3. Bagan Induksi Unit Informasi menjadi Tema Empiris

Induksi intensional dalam penelitian ini terdiri dari dua tahap yaitu: 1) induksi tema menjadi sub-konsep; dan 2) induksi sub-konsep menjadi konsep. Induksi intensional tahap 1 mereduksi 24 (Dua Puluh Empat) tema menjadi 7 (Tujuh) sub-konsep. Proses reduksi 24 tema empiris yang dilakukan merupakan proses reduksi berdasarkan keterhubungan tema-tema empiris yang terdiri dari unit-unit informasi tertentu. Satu tema empiris tidak dibatasi memiliki keterhubungan hanya dengan satu tema empiris lainnya dan membentuk satu sub-konsep, akan tetapi satu tema empiris dapat memiliki keterhubungan dengan beberapa tema-tema empiris lainnya sehingga dapat membentuk beberapa sub-konsep. Tujuh sub-konsep hasil induksi intensional tahap pertama tersebut adalah: 1) Orang Tua Sebagai Awal Terbentuknya Sudut Pandang Anak Terhadap Ruang; 2) Pandangan Anak Terhadap Fungsi Ruang; 3) Perbedaan Ruang Memberikan Bentuk Pendidikan Yang Berbeda; 4) Profil Ruang sebagai Awal Terbentuknya Pilihan Kegiatan Anak; 5) Pilihan Kegiatan dan Gender Berpengaruh Terhadap Respon Anak; 6) Ruang Sebagai Wadah Interaksi Sosial Anak-Anak; 7) Taman Sahabat Sebagai Bentuk Perwujudan Ruang Bermain Untuk Anak-Anak. 


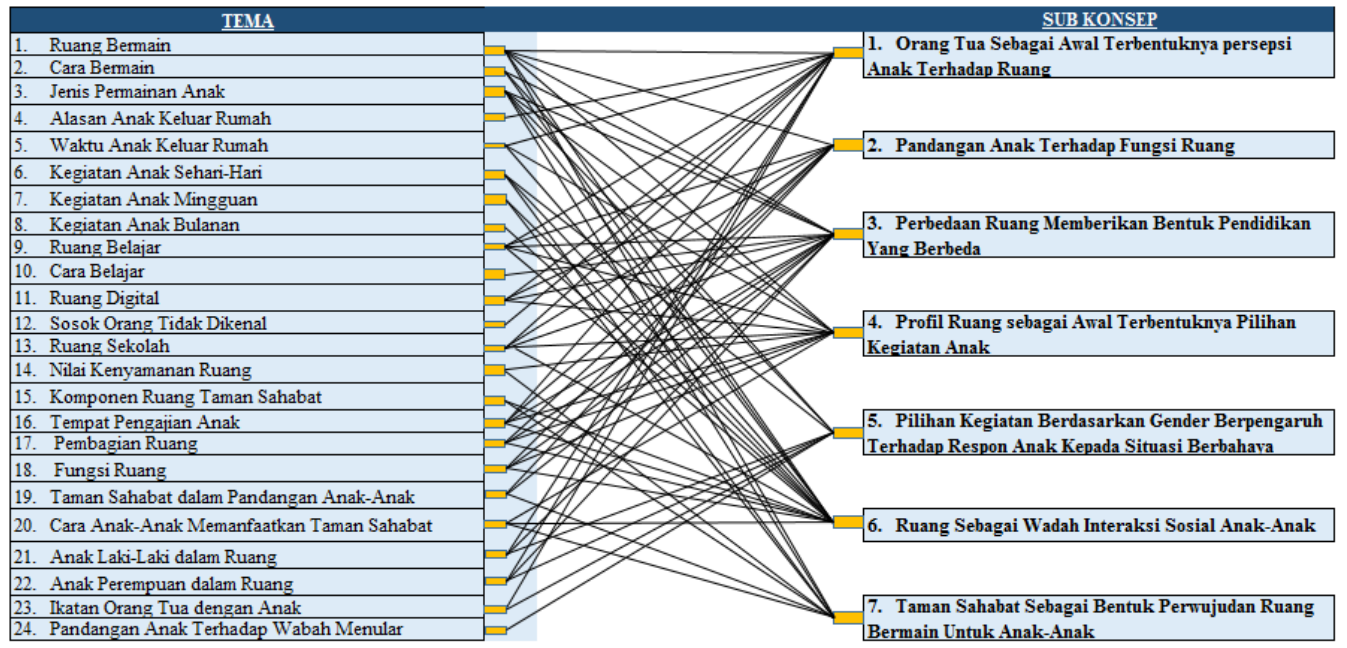

Sumber : hasil analisis, 2020

Gambar 4. Bagan Induksi Tema menjadi Sub-konsep

Ketujuh sub-konsep yang dihasilkan dari tahap induksi intensional tahap I sebelumnya, direduksi pada tahap induksi intensional tahap II dan menghasilkan satu konsep, yaitu "Konsep Nilai Kenyamanan Ruang Menurut Anak-Anak Dipengaruhi Oleh Kegiatan Yang Pernah Dilakukan, Interaksi Sosial Anak, dan Nilai-Nilai Yang Ditanamkan oleh Orang Tua".

Proses induksi intensional tahap II merupakan proses induksi yang dilihat berdasarkan keterhubungan antar sub-konsep sehingga membentuk suatu konsep atau beberapa konsep. Dari 7 sub-konsep pada gambar 3, dapat diidentifikasi bahwa ketujuh sub-konsep tersebut memiliki keterhubungan yang sangat kuat. Keterhubungan tersebut dilihat dari kandungan yang terdapat dalam setiap sub-konsep. Masing-masing tujuh subkonsep tersebut memiliki kandungan informasi mengenai fisik spasial, kegiatan sosial, dan space ruang. Oleh karena itu, konsep yang dihasilkan dari proses induksi tersebut merupakan satu konsep dengan objek yang sama. Konsep tersebut membahas mengenai batasan ruang yang membahas mengenai fisik spasial, kegiatan sosial anak, dan space ruang. 


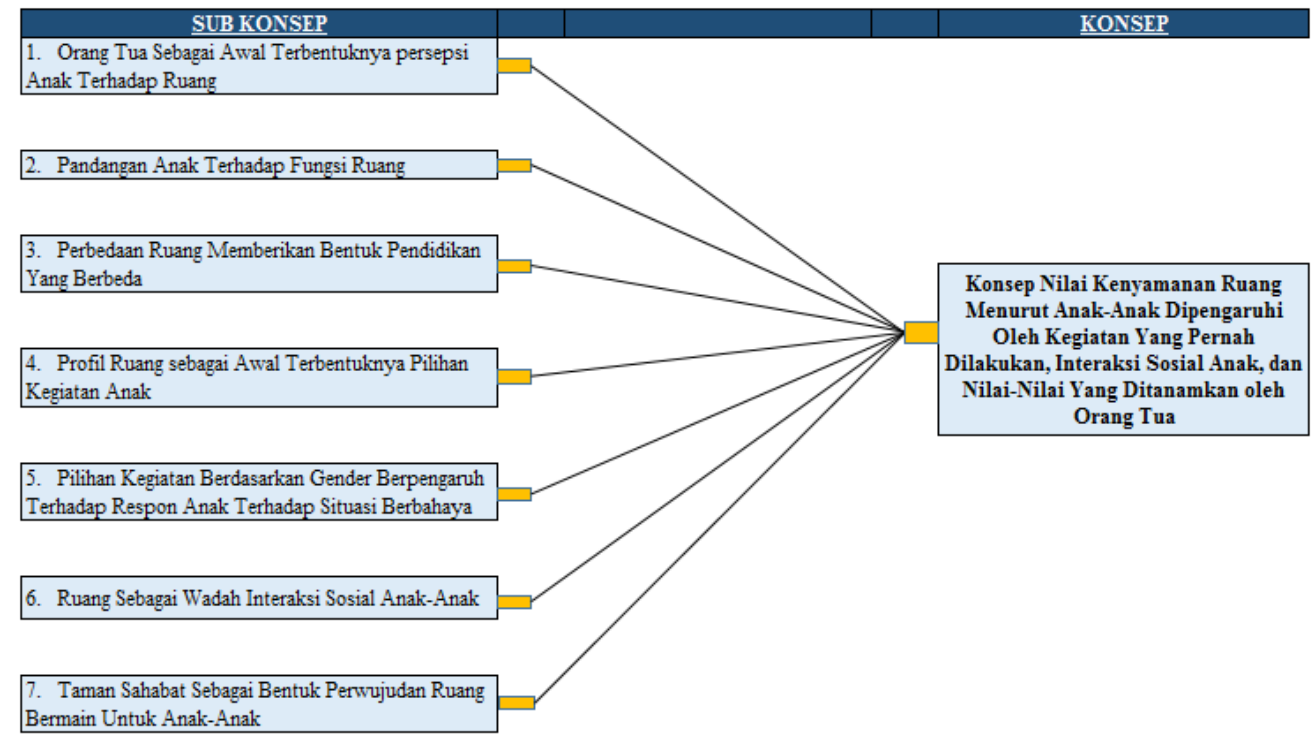

Sumber : hasil analisis, 2020

Gambar 5. Bagan Induksi Sub-konsep menjadi konsep

Konsep ini menggambarkan bahwa dalam berinteraksi dan berkegiatan anak-anak memiliki batasan-batasan ruang masing-masing. Batasan-batasan ini muncul karena setiap ruang memiliki suatu fungsi yang dapat membuat nyaman. Nilai kenyamanan yang dimaksud dibentuk dari 1) kegiatan yang pernah dilakukan oleh anak-anak; 2) interaksi sosial anak; dan 3) nilai-nilai yang ditanamkan oleh orang tua.

Secara tidak sadar, anak-anak memiliki batasan-batasan ruang dalam menentukan pilihan kegiatan. Batasan-batasan ruang ini timbul dari pembagian ruang anak menurut bentuk ruang yang memiliki fungsi-fungsi tertentu, sehingga anak-anak dapat melakukan kegiatan seperti berinteraksi dengan teman-temannya dalam beberapa jenis ruang. Batasan-batasan ruang tersebut tergambar dalam gambar dibawah ini.

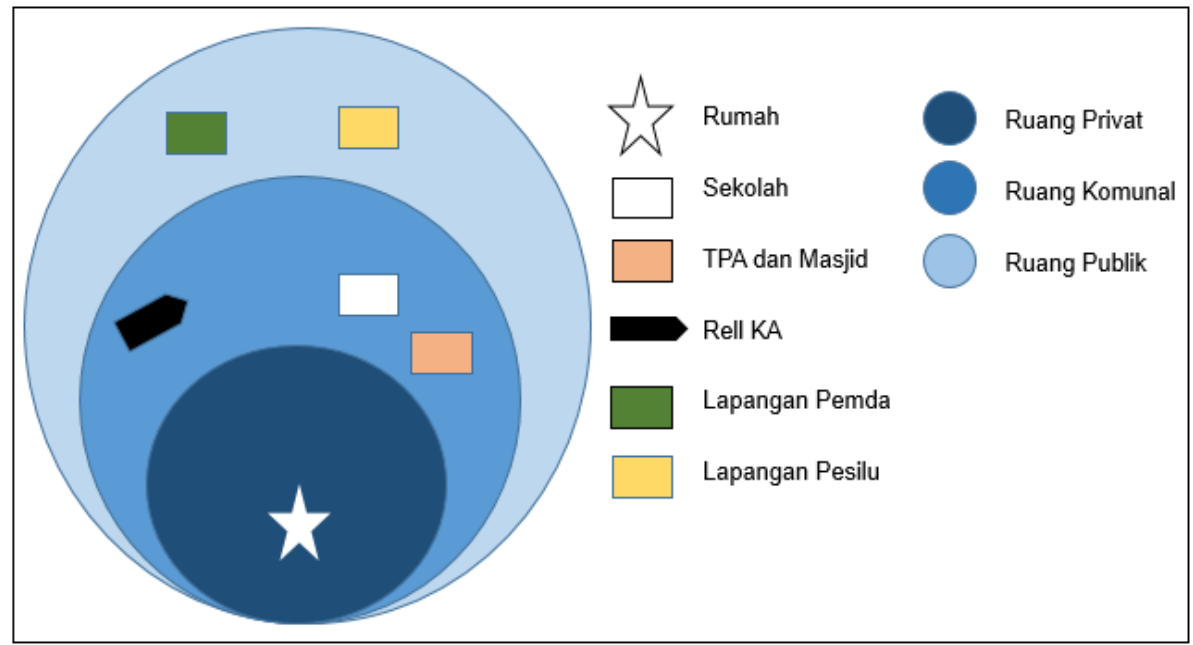

Sumber : hasil analisis, 2020

Gambar 6. Batasan Pelapisan Ruang dalam Perspektif Anak 
Nilai kenyamanan ruang memiliki arti yang berbeda dalam setiap sudut pandang manusia termasuk didalamnya anak-anak. Dalam berinteraksi dan berkegiatan, anak-anak memiliki batasan-batasan ruang tertentu. Batasan-batasan ruang ini muncul karena setiap ruang memiliki fungsi yang berbeda yang melahirkan konsep nilai kenyamanan ruang dari sudut pandang anak-anak. Pembentukan konsep nilai kenyamanan ruang tersebut didasarkan dari harapan anak-anak terhadap ruang yang nyaman menurut sudut pandang anak-anak. Harapan-harapan anak-anak tersebut terhadap ruang yang nyaman melahirkan kriteria-kriteria ruang yang nyaman dari sudut pandang anak-anak di Kecamatan Kotabumi. Kiteria-kriteria tersebut diantaranya:

1. Ruang yang memiliki lokasi tidak jauh dari tempat tinggal anak;

2. Ruang yang memiliki space cukup luas serta kondisi yang sejuk sehingga anakanak dapat bebas melakukan kegiatan, seperti bermain dan belajar;

3. Ruang yang dapat mengakomodasi untuk tiap kelompok umur anak-anak;

4. Ruang yang dapat dinikmati oleh anak-anak tanpa dikenai biaya (free); serta

5. Ruang yang terdiri dari berbagai macam permainan sesuai dengan kelompok usia anak.

Kriteria-kriteria tersebut dapat menjadi sebuah pertimbangan bagi pemerintah dan lembaga terkait dalam merancang ruang publik ramah anak. Perancangan ruang publik tersebut menjadi sangat penting, mengingat dalam mengembangkan rencana kota inklusif terutama dalam penyediaan ruang publik untuk anak-anak belum tersedianya kriteriakriteria dan standarisasi khusus dalam rancangan ruang publik tersebut. Sehingga elemenelemen pendukung dalam ruang publik dinilai tidak memberikan kenyamanan bagi penggunanya. Jaminan kenyamanan sangat penting diperhatikan dalam proses perancangan sebuah ruang. Ruang publik menjadi wadah atau tempat untuk anak-anak melakukan kegiatan. Dengan menerapkan kriteria-kriteria ruang yang nyaman dari sudut pandang anak-anak, maka kenyamanan ruang yang diharapkan anak-anak akan terbentuk. Sehingga mendukung proses tumbuh kembang anak sebagai generasi penerus bangsa.

\section{KESIMPULAN}

Penelitian ini dilakukan untuk mengetahui konsep nilai kenyamanan ruang dari sudut pandang anak-anak di Kecamatan Kotabumi. Berdasarkan hasil analisis data kualitatif dengan menggunakan pendekatan induktif-naturalistik, penelitian ini menunjukkan bahwa anak-anak memiliki nilai pandangan tersendiri mengenai ruang yang nyaman. Kenyamanan ruang yang terbentuk dari sudut pandang anak-anak dibentuk dari: 1) Nilainilai yang ditanamkan oleh orang tua; 2) Kegiatan-kegiatan yang dilakukan oleh anakanak; serta 3) Interaksi sosial anak. Oleh karena itu, upaya perwujudan ruang ramah anak di Kabupaten Lampung Utara selayaknya mempertimbangkan sudut pandang anak-anak terhadap nilai kenyamanan ruang. Sehingga menjamin keberlanjutan implementasi ruang ramah anak serta menjamin keberlanjutan hak-hak anak akan ruang. Upaya yang dapat diterapkan pemerintah dalam proses optimalisasi Taman Sahabat yaitu dengan cara memberikan filter/batasan-batasan antara komponen ruang Taman Sahabat sehingga anak-anak dapat nyaman melakukan aktivitas, memberikan akses free (tidak membayar) kepada anak-anak untuk dapat menggunakan semua permainan yang ada di Taman Sahabat, penambahan beberapa jenis permainan yang sesuai untuk setiap kelompok usia 
anak, serta pengaturan PKL-PKL yang berada di Taman Sahabat sehingga tidak mengganggu aktivitas anak-anak di Taman Sahabat. Selain penting bagi terwujudnya implementasi Kabupaten/Kota Layak Anak juga bernilai khusus bagi anak-anak. Perubahan yang tanpa perhitungan pada komponen ruang Taman Sahabat tidak hanya akan merusak Taman Sahabat, melainkan juga menghapus hak-hak anak untuk mendapatkan ruang yang nyaman.

\section{DAFTAR PUSTAKA}

[1] Banapon, M. F. (2017). Ruang Terbuka Publik Surga Perkotaan. Retrieved from Qureta. http://www.qureta.com

[2] BPS Lampung Utara. (2018). Kabupaten Lampung Utara Dalam Angka. Pemerintah Kabupaten Lampung Utara.

[3] Gehl, J. (2006). Life Between Buildings. Español. Van Nostrand Reinhold Company.

[4] Loncoln S., Y. (1984). Naturalistik Inquiry. Sage Publications.

[5] Pratomo, A., Soedwiwahjono, S., \& Miladan, N. (2019). Kualitas Taman Kota Sebagai Ruang Publik Di Kota Surakarta Berdasarkan Persepsi Dan Preferensi Pengguna. Desa-Kota, 1(1), 84. https://doi.org/10.20961/desa-kota.v1i1.12494.84-95

[6] Setyaningrum, L. (2018). “Keluarga Dongkelan” Sebagai Kesadaran Transendental Keberadaan Dan Keberlanjutan Elemen-Elemen Inti Tata Ruang Dongkelan Kauman. Universitas Gadjah Mada.

[7] Shirvani, H. (1985). The Urban Design Process. Van Nostrand Reinhold Company. 